\title{
Beneficial microbiomes: Biodiversity and potential biotechnological applications for sustainable agriculture and human health
}

\author{
Ajar Nath Yadav ${ }^{1 *}$, Rajesh Kumar², Sunil Kumar' ${ }^{1}$ Vinod Kumar', TCK Sugitha ${ }^{3}$, Bhanumati Singh ${ }^{4}$, \\ Vinay Singh Chauahan ${ }^{4}$, Harcharan Singh Dhaliwal ${ }^{1}$, Anil Kumar Saxena ${ }^{5}$ \\ ${ }^{1}$ Department of Biotechnology, Akal College of Agriculture, Eternal University, Sirmour-173101, India, ${ }^{2}$ Department of Food Technology, Akal College of \\ Agriculture, Eternal University, Sirmour-173101, India, ${ }^{3}$ Department of Agricultural Microbiology, Tamil Nadu Agricultural University, Coimbatore- 641003, \\ India, ${ }^{4}$ Department of Biotechnology, Institute of Life Science, Bundelkhand University, Jhansi-284128, India, ${ }^{5}$ ICAR-National Bureau of Agriculturally Important \\ Microorganisms, Kushmaur, Mau Nath Bhanjan, Mau-275103, India
}

\section{ARTICLE INFO}

Article history:

Received on: July 25, 2017

Accepted on: September 13, 2017

Available online: November 09, 2017

Key words.

Biodiversity,

Biofortification,

Malnutrition,

Microbiomes,

Probiotic

\section{ABSTRACT}

The beneficial microbes plays an important role in medical, industrial, and agricultural processes. The precious microbes belong to different groups including archaea, bacteria, and fungi which can be sort out from different habitat such as extreme environments (acidic, alkaline, drought, pressure, salinity, and temperatures) and associated with plants (epiphytic, endophytic, and rhizospheric) and human. The beneficial microbes exhibited multifunctional plant growth promoting (PGP) attributes such as $\mathrm{N}_{2}$-fixation, solubilization of micronutrients (phosphorus, potassium and zinc), and production of siderophores, antagonistic substances, antibiotic, auxin, and gibberellins. These microbes could be applied as biofertilizers for native as well as crops growing at diverse extreme habitat. Microbes with PGP attributes of $\mathrm{N}_{2}$-fixation, $\mathrm{P}$-, and K-solubilization could be used at a place of NPK chemical fertilizers. Agriculturally, important microbes with $\mathrm{Fe}$ - and Zn-solubilizing attributes can be used for biofortification of micronutrients in different cereal crops. The biofertilizers are an eco-friendly technology and bioresources for sustainable agriculture and human health. In general, the concentrations of micronutrient in different crops are not adequate for human nutrition in diets. Hence, consumption of such cereal-based diet may result in micronutrient malnutrition and related severe health complications. The biofortification approach is getting much attention to increase the availability of micronutrients, especially $\mathrm{Fe}$ and $\mathrm{Zn}$ in the major food crops. The beneficial microbes can be used as probiotic as functional foods for human health. Probiotics microbes such as Bifidobacterium, Lactobacillus, Methanobrevibacter, Methanosphaera, and Saccharomyces are increasingly being used as dietary supplements in functional food products. The microbes with beneficial properties could be utilized for sustainable agriculture and human health.

\section{INTRODUCTION}

Extreme environments represent unique ecosystems which harbor novel biodiversity of microbes with the ability to survive at diverse environmental conditions. India is one among 12 mega-biodiversity countries and 25 hotspots of the richest and highly endangered ecoregions of the world. The microbiomes of have been reported in diverse environmental habitat such high/low temperature, hypersalinity, water deficiency, and high/low $\mathrm{pH}$. To survive under such extreme conditions, these organisms referred to as extremophiles have developed adaptive features which permits them to grow optimally under one or more environmental extremes, while polyextremophiles grow optimally under multiple conditions. These extremophiles can grow optimally

\footnotetext{
*Corresponding author

Ajar Nath Yadav,

Department of Biotechnology, Akal College of Agriculture,

Eternal University, Sirmour-173101, India.

Email:ajar@eternaluniversity.edu.in
}

in some of the earth's most unreceptive environments of temperature $\left(-2^{\circ}-20^{\circ} \mathrm{C}\right.$ - psychrophiles; $60^{\circ}-115^{\circ} \mathrm{C}$ - thermophiles), salinity $(2-5 \mathrm{M}$ $\mathrm{NaCl}$ - halophiles), and $\mathrm{pH}(<4$ acidophiles and $>9$ - alkaliphiles). Among diverse extreme habitats, thermal springs represent unique ecological niches and harbor both mesophilic and thermophilic members of archaea and bacteria [1-3]. Phylogenetic characterization of microbiota has been undertaken for geothermal springs worldwide. The different thermal springs such as Bakreshwar, Balarampur, Chumathang, Manikaran, and Vashisht are present in India, which represent an unusual niche for thermophilic microbes $\left(60-100^{\circ} \mathrm{C}\right)$, which can be potential sources of novel genes, allele, and microbiota [4-6]. Prospecting low-temperature habitats have led to the isolation of a great diversity of psychrophilic/psychrotrophic microbiomes. The Indian Himalayas represent cold habitat a niche for selection of novel psychrotrophic microbes for different biotechnological, agricultural, and industrial applications. Psychrophilic microorganisms are potential bioresources of novel pigments (as food additives), extracellular enzymes (amylase, cellulase, chitinase, laccase, lipase, pectinase, protease, xylanase, $\beta$-galactosidase, and $\beta$-glucosidase), 
Yadav, et al.: Journal of Applied Biology \& Biotechnology 2017;5(6):45-57

exopolysaccharide production, and antifreeze compounds, which can be valuable in agriculture as inoculants (plant growth promoting [PGP] microbes) or biocontrol agents in extreme cold and high altitude habitats [7-9]. Microbial research in hypersaline environments has also attracted the interest of researchers due to various biotechnological and agricultural applications. Soda lakes and deserts represent the most stable naturally occurring alkaline environments on Earth. The different hypersaline lakes such as Sambhar Lake (Rajasthan), Chilka Lake (Odisha), and the Great Rann of Kutch (Gujarat) are typical saline environments in India, and novel and efficient microbiomes from hypersaline environments have been reported and characterized for its biotechnological applications in agriculture, industry, and medicines $[10,11]$.

Water-deficient/low-moisture conditions coupled with high temperatures in arid deserts lead to enrichment of microbial communities that can survive extreme variations in temperature and drought. Such environments encompass typically poor soils with low organic content and limited amounts of bioavailable inorganic nutrients. The desert microbiomes are not only responsible for the productivity, biogeochemical cycling of elements, and ecosystem balance but also for soil neogenesis and improvement of soil structure. The drought-tolerant microbes from hot deserts have been isolated and characterized for PGP under the rainfed conditions [12,13]. Extremes of high (alkaline) and low (acidic) $\mathrm{pH}$ also influence the buildup of microbial population and in turn soil productivity. If the soil is acidic, the availability of essential micronutrients such as $\mathrm{P}, \mathrm{Ca}$, $\mathrm{Mg}$, and molybdenum are affected. Very few reports are available on the diversity and distribution of microbiomes in acidic soils $[14,15]$. Another useful extreme environment is the mangrove ecosystems which is mostly nutrient-deficient, especially in terms of $\mathrm{N}_{2}$ and P. Inspite of this, mangroves can be highly productive, which can be attributed to microbial activity leading to major nutrient transformations [16].

The plant microbiomes can be grouped as rhizospheric microbes (living in soil near the roots), epiphytic microbes (colonizing on the phyllosphere), and endophytic microbes (residing inside tissue). In general, there are three kinds of plant-microbes interactions are considered, i.e., epiphytic, endophytic, and rhizospheric. The rhizosphere is the zone of soil influenced by roots through the release of substrates that affect microbial activity. The rhizospheric microbes have the ability to attach to the root surfaces allowing these to derive maximum benefit from root exudates. The population and abundances of rhizospheric microbes have been affected by several factors such as soil type, soil $\mathrm{pH}$, and other environmental conditions surrounding any plants. A number of microbial species belonging to different genera such as Acinetobacter, Arthrobacter, Aspergillus, Azospirillum, Bacillus, Burkholderia, Enterobacter, Flavobacterium, Haloarcula, Halococcus, Haloferax, Methylobacterium, Paenibacillus, Penicillium, Piriformospora, Pseudomonas, Rhizobium, and Serratia were revealed from the rhizosphere of different crop plants [12,17-22].

The phyllosphere is a common and special niche for synergism between microbes and plant. The plant part, especially, leaves are exposed to dust and air currents, resulting in the establishments of typical flora on their surface aided by the cuticles, waxes, and appendages, which help in the anchorage of microbes. The phyllospheric microbes may survive or proliferate on leaves depending on the extent of influences of material in leaf diffusates or exudates. The phyllospheric microbes may perform an effective function in controlling the airborne pathogens inciting plant disease. Microbes on leaf surface are said to be extremophiles as they can tolerate low/high temperature $\left(5-55^{\circ} \mathrm{C}\right)$ and UV radiation. Many microbes such as Achromobacter, Bacillus, Beijerinckia, Burkholderia, Flexibacterium, Methylobacterium, Micrococcus, Micromomospora, Nocardioides, Pantoea, Penicillium, Planomonospora, Pseudomonas, Streptomyces, and Xanthomonas have been reported in the phyllosphere of different crop plants [15,23-27].

The microbes isolated from inside the plant tissues (endophytes) are referred to those microorganisms, which colonize in the inner of the plant parts, namely, root, stem, or seeds without causing any harmful effect on the host plant. Endophytic microbes enter in host plants mainly through wounds, naturally occurring as a result of plant growth or through root hairs and at epidermal conjunctions. Endophytes may be transmitted either vertically (directly from parent to offspring) or horizontally (among individuals). Microbes reach the rhizosphere by chemotaxis toward root exudates components followed by attachment. The preferred site of attachment and subsequent entry are the apical root zone with a thin-walled surface root layer, such as the cell elongation zone and the root hair zone with small cracks caused by the emergence of lateral roots. Microbial traits putatively involved in endophytic colonization of plant roots. For penetration, the microbes have to produce cellulolytic enzymes required to hydrolyze the exodermal walls, such as endoglucanases and endopolygalacturonidases [22]. Endophytic microbes exist within the living tissues of most plant species in the form of symbiotic to slightly pathogenic. A large number of endophytic microbial species such as Achromobacter, Burkholderia, Burkholderia, Curtobacterium, Enterobacter, Gluconoacetobacter, Herbaspirillum, Klebsiella, Microbiospora, Nocardioides, Pantoea, Planomonospora, Pseudomonas, Serratia, and Streptomyces have been identified from different host plants [22,28-33].

Abiotic stresses, such as acidity, alkalinity, drought, extremes of low and high temperature, heavy metals, and soil salinity, cause severe yield loss in agricultural crops. There are many reports on microbial diversity from extreme environments, for example, low temperature [9,34-36], high temperature [3-6,37], saline soil [38], drought [39], acidic soil [39], and alkaline soil [11,39]. Microbe isolated and sort out from extreme environments may have exhibited PGP attributes, and thus, these abiotic stress tolerant microbes can be applied for plant growth under respective abiotic stress conditions.

The microbiomes associated with different crops possess multifunctional PGP attributes, and these microbes promote the growth of plant directly by production of plant growth regulators (indole3 -acetic acid, cytokinins, gibberellins, and abscisic acid); biological nitrogen fixation; solubilization of phosphorous, potassium and zinc; or indirectly by production of ACC deaminase, ammonia, antibiotics (2,4-diacetylphloroglucinol, kanosamine, neomycin A, phenazine1-carboxylic acid, pyocyanin, pyoluteorin, and pyrrolnitrin), hydrocyanic acid (HCN), lytic enzymes (chitinase, lipase protease, $\beta$-1,3-glucanase), and siderophores [16]. Currently, there has been an increased curiosity in the development of new functional foods and their assimilation in a healthy diet. Such products, and especially probiotics, exert a beneficial effect on host-gut microbiota after consumption and may be proficient to prevent several diseases. Probiotics are defined as live microbiomes which when administered in ample amounts confer a health benefit on the host. The present review revealed about microbes reported from different source including extreme microbiomes, plant microbiome, human microbiomes, and its biotechnological application in agriculture, industry, and for human health. Microbiomes having multifunctional PGP attributes can be utilized as bio-inoculants for sustainable agriculture. 


\section{BIODIVERSITY OF BENEFICIAL MICROBIOMES}

The extreme environments possess the potential and novel microbial diversity. Among diverse microbiomes, actinobacteria, firmicutes, and proteobacteria are omnipresent in the environment and play a noteworthy role in agriculture, medicine, and industry. Extreme environments can be a source for novel species of microbes, as they can tolerate extremes of $\mathrm{pH}$, temperature, salinity, and moisture stress. The different groups of microbes have been reported as plant microbiomes (epiphytic, endophytic, and rhizospheric) and from different natural and extreme environments worldwide. The microbiomes belong to all three domains archaea, eubacteria, and fungi, which included different phylum mainly: Archaea (Crenarchaeota and Euryarchaeota), bacteria (Actinobacteria, Bacteroidetes, Chloflexi, Cyanobacteria, Firmicutes, and Proteobacteria), and fungi (Ascomycota and Basidiomycota) (Fig. 1). The proteobacteria were further grouped as $\alpha-, \beta-, \gamma-$, and $\delta$-proteobacteria.

The low-temperature habitat represents hot spots of biodiversity, and several novel cold-adapted microbial species have been sort out from cold environments including Cellulophaga algicola [40], Cryobacterium roopkundense [41], Exiguobacterium soli [42], Flavobacterium frigidarium [43], Flavobacterium psychrolimnae [44], Glaciimonas frigoris [45], Hymenobacter roseosalivarius [46], Lacinutrix jangbogonensis [47], Massilia eurypsychrophila [48], Octadecabacter arcticus [49], Oleispira antarctica [50], Pedobacter arcticus [51], Pseudomonas extremaustralis [52], Psychrobacter pocilloporae [53], Psychromonas ingrahamii [54], Sphingobacterium psychroaquaticum [55], and Sphingomonas glacialis [56]. Along with novel species of psychrotrophic microbes, some microbial species such as Arthrobacter nicotianae, Brevundimonas terrae, Paenibacillus tylopili, and Pseudomonas cedrina have been isolated and characterized for multifarious PGP attributes at low temperatures from cold deserts of NW Himalayas [7]. In a study by Yadav et al. [8], the microbial species Alishewanella sp., Aurantimonas altamirensis, Bacillus baekryungensis, Bacillus marisflavi, Desemzia incerta, Paenibacillus xylanexedens, Pontibacillus sp., Providencia sp., Pseudomonas frederiksbergensis, Sinobaca beijingensis, and Vibrio metschnikovii have been isolated and characterized for low-temperature tolerance and PGP attributes first time from high altitude and low-temperature environments of Indian Himalayas. Wheat associated psychrotrophic bacteria such as Arthrobacter methylotrophus and Pseudomonas rhodesiae have been reported first time from wheat growing in North hills zone of India [28]. In a specific search of economically important Bacillus and Bacillus derived genera (BBDG) at low temperature, various BBDGs such as Bacillus psychrosaccharolyticus, Bacillus amyloliquefaciens, Bacillus altitudinis, Bacillus muralis, P. tylopili, Paenibacillus pabuli, Paenibacillus terrae, and Paenibacillus lautus with efficient PGP attributes have been reported first time by Yadav et al. [57].

Thermal springs represent extreme niches of microbiomes as bioresources of biotechnologically important microbes with potential applications in industry and agriculture. In the past few decades, several attempts have been made for isolation and characterization of microbiomes of thermal springs present in worldwide. Novel and efficient thermophilic microbes have been isolated and characterized from thermal extreme environments of world such as Thermotoga elfii [58], Thermotoga hypogeal [59], Thermoanaerobacter uzonensis [60], Bacillus thermophilus [61], and Herbinix luporum [62]. In the study by Yadav et al. [39], 195 isolates from Indian hot water springs (Manikaran, Balarampur, Vashisht, Chumathang, and Bakreshwar) have been isolated and characterized for different beneficial attributes of hydrolytic enzymes production and PGP under normal as well as high-temperature conditions. The many nichespecific Bacillus and Bacillus and derived genera (BBDG) have been reported from thermal spring, for example, Bacillus fusiformis (B-10) from Bakreshwar and Brevibacillus from Vashisht and Balrampur [39].

Soil salinity is an important limiting factor for PGP of crops, especially in arid and semi-arid regions worldwide. Haloarchaea thrive in hypersaline environments and have ability to survive with salt concentrations approaching saturation. The microbiomes of saline habitats have been isolated and identified to be present in halobacteriaceae family such as Haloarcula argentinensis, Halobacterium sp., Halococcus hamelinensis, Haloferax alexandrines, Haloferax larsenii, Haloferax volcanii, Halolamina pelagic, Halostagnicola kamekurae, Haloterrigena thermotolerans, Natrinema sp., and Nanoarchaeum mannanilyticum. The haloarchaea have been isolated from many halophilic plants growing in hypersaline region of Rann of Kutch and characterized for different PGP attributes under hypersaline conditions $[38,63,64]$. In study by Yadav et al. [8], a large number of halophilic or halotolerant species such as Bacillus halodurans (ABSL-8), Bacillus methanolicus (ABSL-11), Ammoniphilus sp. (ABSL-2), Halobacillus trueperi (ABSL-21), Bacillus vallismortis (ABSL-23), and Halobacillus dabanensis (ABSL-29) from Sambhar lake, Marinococcus halophilus (ABK-3) from Rann of Kutch, and Pontibacillus sp. (AB-2) from Chilka lake have been reported and characterized for different potential attributes for agriculture, industry, and human welfare.

\section{BENEFICIAL MICROBES FOR SUSTAINABLE AGRICULTURE}

Plant microbiomes are agriculturally important bioresources for agriculture as beneficial microbes may enhance plant growth and improve plant nutrition uptake through solubilization of $\mathrm{P}, \mathrm{K}$, and $\mathrm{Zn}$, nitrogen fixation, and other mechanisms including siderophore production (microbes-mediated biofortification of $\mathrm{Fe}$ in different crops). Beneficial microbes may increase crop yields, remove contaminants, inhibit pathogens, and produce fixed nitrogen or novel substances. The growth stimulation by plant microbiomes can be a consequence of biological nitrogen fixation, production of plant growth regulators such as IAA, gibberellic acids, and cytokines, and biocontrol of phytopathogens through the production of antibiotic, antifungal, or antibacterial agents, Fe-chelating compounds production, nutrient competition and induction of acquired host resistance, or enhancing the bioavailability of minerals. Sustainable agriculture requires the use of strategies to increase or maintain the current rate of food production while reducing damage to the environment and human health. The use of plant microbiomes as PGP agents/biofertilizers is an eco-friendly alternative to conventional agricultural technology. There are several ways in which different PGP microbes have been reported to directly facilitate the proliferation of their plant hosts. The PGP microbes can fix atmospheric nitrogen and supply it to plants. The plant microbiomes with multifarious PGP ability synthesize several plant growth regulators that can act to enhance various stages of plant growth; they may have mechanisms for the $\mathrm{P}, \mathrm{K}$, and $\mathrm{Zn}$ that will become more available for plant growth and development; and they may synthesize some less well-characterized, low-molecularmass compounds or enzymes that can modulate plant growth and development. The indirect plant growth mechanism occurs when microbes prevent the growth of other plant pathogenic microbes 
Yadav, et al.: Journal of Applied Biology \& Biotechnology 2017;5(6):45-57

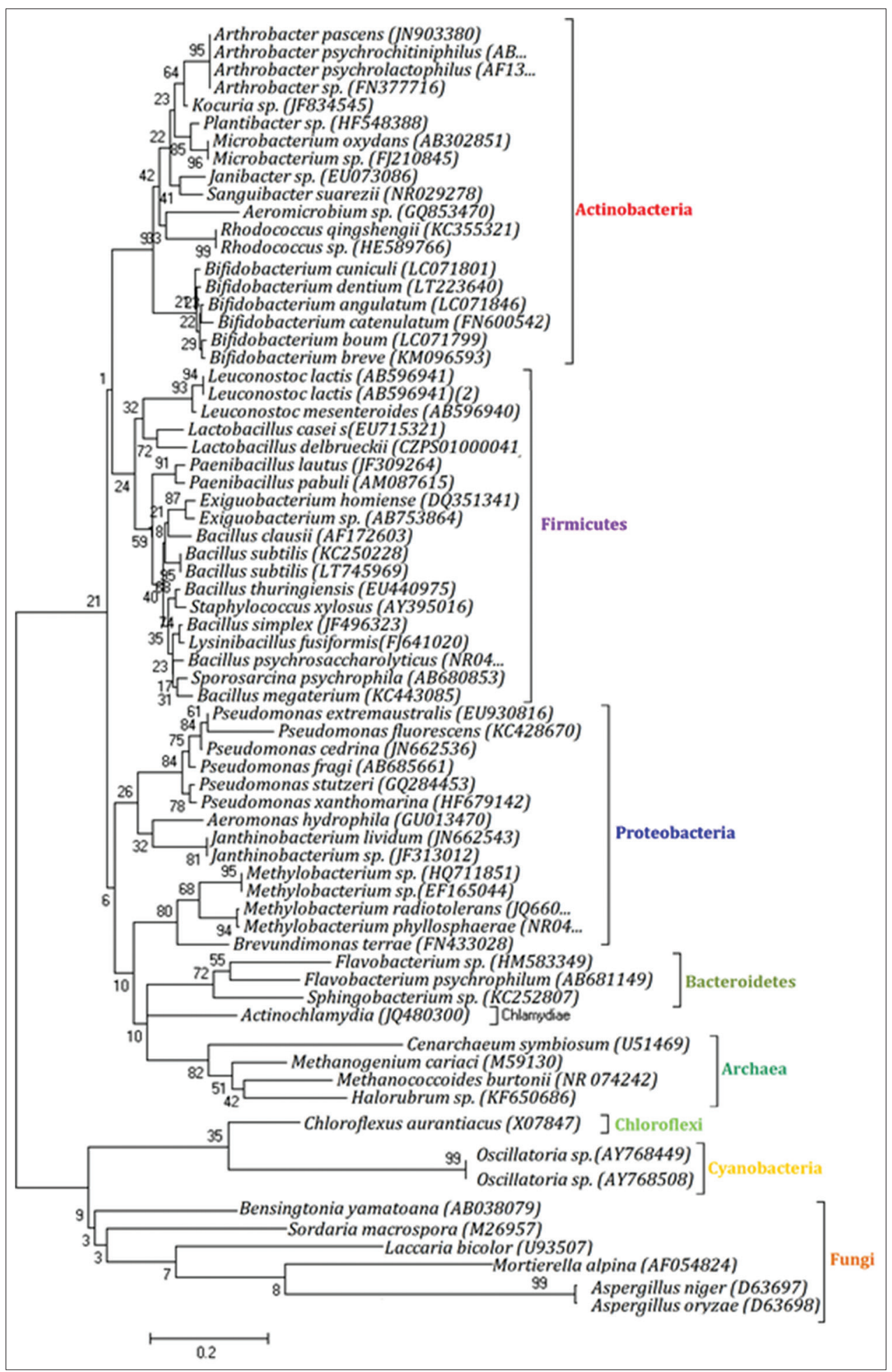

Fig. 1: Phylogenetic tree showed the relationship among beneficial microbiomes for agriculture, industry, and human health. 16S/5.8S rRNA gene sequences obtained from NCBI database, sequence alignment was performed using the CLUSTAL W program, and trees are constructed using maximum likelihood method with an algorithm using MEGA4 software. One thousand bootstrap replicates were performed. Bootstrap values are indicated on the branches.

by mechanisms of production of ammonia, hydrogen cyanide, Fechelating compounds (siderophores), $\beta$-1, 3-glucanase, chitinases, cellulase, lipase, antibiotics, and different fluorescent pigment. World agriculture faces a great loss every year incurred from infection by pathogenic organisms. The most promising way to increase crops productivity is the application of microbe for control of disease (Table 1).

Nitrogen is the one of the major limiting factors for plant growth, and the application of $\mathrm{N}_{2}$-fixing microbes as biofertilizers has emerged 
Yadav, et al:: Beneficial microbiomes for sustainable agriculture and human health 2017;5(6):45-57

as one of the most efficient and eco-friendly sustainable methods for increasing the growth and yield of crop plants. The chemical nitrogen fertilizers may be replaced by microbes having nitrogen- fixing ability which could lead to more productive and sustainable agriculture without harming the environment. The plant microbiomes and microbes from different habitat in normal as well as extreme

Table 1: Microbes with PGP attributes for agricultural application for the amelioration of diverse abiotic stresses.

\begin{tabular}{|c|c|c|c|}
\hline Plant growth promoting microbes & Abiotic stress & Response & Reference \\
\hline Achromobacter xylosoxidans 249 & Salinity stress & Growth and SOD activity & {$[73]$} \\
\hline Aeromonas hydrophila MAS-765 & Salinity stress & Alleviate salinity, growth & {$[74]$} \\
\hline Aeromonas vaga BAM-77 & Alkalinity stress & Growth and yield & {$[75]$} \\
\hline Aeromonas vaga BAM-77 & Salinity stress & Growth and yield & {$[75]$} \\
\hline Arthrobacter sulfonivorans IARI-L-16 & Cold stress & Growth and alleviation & {$[8]$} \\
\hline Azospirillum brasilense $\mathrm{NO}_{40}$ & Drought and heat stress & Improved homeostatic & {$[76]$} \\
\hline Azospirillum brasilense $\mathrm{Sp} 245$ & Drought and heat stress & Coleoptiles growth & {$[77]$} \\
\hline Azospirillum brasilense Sp245 & Drought and heat stress & Grain yield, mineral quality & {$[78]$} \\
\hline Azospirillum brasilense Sp245 & Cold stress & Affected dry weight & {$[79]$} \\
\hline Azospirillumlipoferum AZ1, AZ9, AZ45 & Drought and heat stress & Alleviate the drought stress & {$[80]$} \\
\hline Bacillus aerophilus BSH15 & Acidic stress & Growth and alleviate acidity & {$[81]$} \\
\hline Bacillus alcalophilus BCZ14 & Drought and heat stress & Growth, yield, stress & {$[81]$} \\
\hline Bacillus altitudinis IARI-HHS2-2 & Cold stress & Growth and yield & {$[28]$} \\
\hline Bacillus altitudinis BNW15 & Alkalinity stress & Growth and alleviate alkalinity & {$[81]$} \\
\hline Bacillus amyloliquefaciens BNE12 & Salinity stress & Growth and alleviate salinity & {$[81]$} \\
\hline Bacillus amyloliquefaciens IARI-HHS2-30 & Cold stress & Growth and alleviation & {$[82]$} \\
\hline Bacillus aryabhattai BCZ17 & Drought and heat stress & Growth, yield, stress & {$[81]$} \\
\hline Bacillus endophyticus BNW9 & Alkalinity stress & Growth and alleviate alkalinity & {$[81]$} \\
\hline Bacillus licheniformis HSW-16 & Salinity stress & Growth and productivity & {$[83]$} \\
\hline Bacillus nanhaiensis IARI-THD-20 & Alkalinity stress & Growth and alleviation & {$[15]$} \\
\hline Bacillus safensis W10 & Drought and heat stress & Plant growth and yield & {$[84]$} \\
\hline Burkholderia phytofirmans PsJN & Drought and heat stress & Growth and grain yield & {$[85]$} \\
\hline Cellulomonas turbata AS1 & Cold stress & Growth and yield & {$[86]$} \\
\hline Flavobacterium psychrophilum HHS2-37 & Cold stress & Growth and yield & {$[28]$} \\
\hline Klebsiella sp. SBP-8 & Salinity stress & Plant growth and yield & {$[87]$} \\
\hline Lysinibacillus fusiformis IARI-THD-4 & Acidic stress & Growth and yield & {$[15]$} \\
\hline Micrococcus roseus SW1 & Acidic stress & Growth and yield & {$[88]$} \\
\hline Paenibacillus polymyxa $\mathrm{BNH} 18$ & Cold stress & Growth, alleviate cold & {$[81]$} \\
\hline Paenibacillus xylanexedens BNW24 & Alkalinity stress & Growth and alleviate alkalinity & {$[81]$} \\
\hline Pantoea intestinalis DSM $28113^{\mathrm{T}}$ & Drought and heat stress & Alleviate drought stress & {$[89]$} \\
\hline Piriformospora indica $(\mathrm{Pi})$ & Drought and heat stress & Drought resistance, growth & {$[90]$} \\
\hline Planococcus salinarum BSH13 & Acidic stress & Growth and alleviate acidity & {$[81]$} \\
\hline Pseudomonas fluorescens 153 & Salinity stress & Salinity stress, growth & {$[91]$} \\
\hline Pseudomonas lurida $\mathrm{M}_{2} \mathrm{RH}_{3}$ & Cold stress & Growth and nutrient uptake & {$[92]$} \\
\hline Pseudomonas poae IARI-NIAW2-1 & Drought and heat stress & Growth, yield & {$[13]$} \\
\hline Pseudomonas putida AKMP7 & Drought and heat stress & Growth, alleviate heat stress & {$[93]$} \\
\hline Pseudomonas putida 108 & Salinity stress & Salinity stress, growth & {$[91]$} \\
\hline Pseudomonas rhizosphaerae IARI-DV-26 & Alkalinity stress & Growth and alleviation & {$[81]$} \\
\hline Pseudomonas sp. $\mathrm{NARs}_{9}$ & Cold stress & Germination, shoot, root lengths & {$[94]$} \\
\hline Rhodobacter sphaeroides IARI-NIAW1-7 & Drought and heat stress & Growth, yield & {$[13]$} \\
\hline Serratia marcescens 73 & Salinity stress & Growth and SOD activity & {$[73]$} \\
\hline Sporosarcina sp. BNH20 & Cold stress & Growth, alleviate cold & {$[81]$} \\
\hline Staphylococcus arlettae BNW27 & Alkalinity stress & Growth and alleviate alkalinity & {$[81]$} \\
\hline Staphylococcus epidermidis IARI-THW-28 & Acidic stress & Growth and yield & {$[15]$} \\
\hline
\end{tabular}


conditions are known to fix atmospheric nitrogen. There are many groups of microbes reported as nitrogen fixation with associative or free livings such as Arthrobacter, Azospirillum, Azotobacter, Bacillus, Enterobacter, Gluconoacetobacter, Herbaspirillum, Klebsiella, Pseudomonas, and Serratia (Table 1) [65-69].

Among different major essential macronutrient, phosphorus (P) is one of best sources for biological growth and development of crops. Microorganisms offer a biological rescue system capable of solubilizing the insoluble inorganic $\mathrm{P}$ of soil and make it available to the plants. The ability of many microbes to convert insoluble $\mathrm{P}$ to an accessible form (orthophosphate) is an important trait in PGP microbes for increasing plant yields for sustainable agriculture. The rhizospheric P-solubilizing microbes could be a promising bioresource for PGP agents in agriculture. Phosphate solubilization is a common trait among microbes associated with different crops. The plant microbiomes from wheat, rice, maize, and legumes and microbiomes of extremes habitat were able to solubilize mineral P in plate assays. There are many reports on microbe having capability to solubilized phosphorus under the normal and different abiotic stresses conditions, which belong to Arthrobacter, Azotobacter, Burkholderia, Enterobacter, Halolamina, Pantoea, Pseudomonas, Citrobacter, and Azotobacter (Table 1) [63,70-72].

Phytase (myo-inositol 1,2,3,4,5,6-hexakisphosphate phosphohydrolase) is a hydrolytic enzyme which hydrolyzes phytate (myo-inositol 1,2,3,4,5,6-hexakisphosphate; $\mathrm{IP}_{6}$ ) complexes into myoinositol, inorganic phosphate, and divalent cations. This is produced by bacteria [95], fungi [96], and plants [97] with tremendous diversity in various agro-climatic and environmental conditions. Four classes of phytases, namely, (HAPhy), (BPPhy), (PAPhy), and (CPhy), have been reported in the literature based on catalytic and sequence features [98]. These have also been categorized as 3-phytase and 4/6-phytase based on initial site of action and liberation of inorganic phosphate from phytate structure [99]. Several applications of phytases and phytaseproducing microbes have been reported leading to tremendous opportunities in using these microbes for beneficial purposes. Bacterial isolates and their consortiums for PGP have been well documented in several reports $[95,100]$. Although microbes promote the growth of plants by different means, the presence of enough organic phosphorus (as phytate) in soil increases the significance of phytate-hydrolyzing microbes in soil for efficient utilization of this source of phosphorus by plants as it is a major element determining proper health of plant. An application of phytase-producing bacterial isolates (Advenella sp., Cellulosimicrobium sp., Acromobacter sp., Tetrathiobacter sp., and Bacillus sp.) has been resulted in improved growth of plants. Studies on potential PGP attributes in phytase-positive bacterial isolates have revealed multiple attributes of PGP including the production of plant growth hormones and siderophores, solubilization of phosphorus, and inhibition of plant pathogenic fungal growth $[95,100]$. These attributes with additional phytase production potential make these microbes more useful as they also reduce the use of phosphorus fertilizers, thereby decreasing environmental phosphorus pollution and contribute toward sustainable agriculture. Reducing environmental phosphorus pollution is of great importance in areas of intensive livestock production of monogastric animals, where unavailable phosphate excreted and deposited in nearby water bodies leading to its eutrophication. Excess phosphorus in such places causes algal blooms and death of aquatic life therein [99]. Phytase-producing microbes or neutral phytases have a potential role to be used as a supplement in meals of aquatic animals [101,102].
The indirect mechanism of plant growth occurs when one type of microbes prevents the detrimental effects of other type of microbes having pathogenic capability. These beneficial PGP microbes have ability to produced siderophores (Fe-chelating compounds), chitinases, antibiotics, different fluorescent pigment, and hydrogen cyanide production $[103,104]$. Biological controls are eco-friendly and cost-efficient and involved in improving the soil consistency and maintenance of natural soil flora. To act efficiently, the biocontrol agent should remain active under large range of conditions, namely, high/low temperature, $\mathrm{pH}$, and salinity. The production of siderophores by microbe is beneficial to plants because it can inhibit the growth of plant pathogens and also for uptake of Fe to plant and finally to seed which said to be a best way for biofortification of Fe in different cereal crops. Siderophores have been implicated for both direct and indirect enhancement of plant growth by PGP microbes.

Biofertilizers are beneficial microbes which can help plant growth and enrichment of the nutrients of the soil by enhancement of the availability of the nutrients to the crops. The production of the healthy crops so as to meet the demands of the world's expanding population mainly relies on the type of the fertilizers which are basically used to supplement all the nutrients to the plants, but more reliability on the chemical fertilizers is damaging the environmental ecology as well as affecting the human health with great severity. Thus, the use of the microbes as biofertilizers is considered as an alternative to chemical fertilizers so as to improve the fertility of the soil as well as increasing the productivity of the crops. These microbes are considered to be the biopotential and a novel tool for providing substantial benefits to the agriculture. These microbes colonize the roots and stimulate the growth. The PGP microbes possess multifarious PGP attributes, which help in plant growth directly by production of plant growth hormones and $\mathrm{N}_{2}$-fixation; solubilization of phosphorous, potassium, and zinc; or indirectly by production of ACC deaminase, ammonia, antibiotics, hydrocyanic acid, lytic enzymes, and siderophores. Extensive works on the biofertilizers are available which reveals that these microbes have the capability of providing the required nutrients to the crops in amounts which are sufficient for the enhancement of yield of the crops. Microbes having multifunctional PGP attributes can be utilized as ecofriendly biofertilizers for sustainable agriculture $[13,28,70,105,106]$.

\section{BENEFICIAL MICROBES FOR HUMAN HEALTH}

The beneficial microbes from different natural and extreme environments as well as associated with plant could be used for different processes. Apart from their application in agricultural sciences, phytase-producing microbes provide great promises for nutritional applications in human food and animal feed. Exogenous phytase addition has been used to enhance the mineral bioavailability [107], and dephytinization by the addition of exogenous phytase in porridges of different cereal crops such as maize, oats rice, and wheat has been shown to improve iron bioavailability in human [108]. It has been demonstrated that phytic acid significantly reduces (about $86 \%$ ) bioavailability of $\mathrm{Fe}$ from infant cereal diets in an in vitro digestion study in a Caco-2 cell model [109], and dephytinization markedly improved $\mathrm{Fe}$ and $\mathrm{Zn}$ bioavailability in these diets [110]. Park et al. [111] reported a decrease of $20-40 \%$ in phytate content in a reaction time of 30-60 min by addition of alkaline phytase to whole-wheat bread. Phytate degradation enhanced the Fe and $\mathrm{Zn}$ availability of bread with a maximum increase of 10 fold in the level of dialyzable Fe. According to Sanz-Penella et al. [112], the addition of phytase probiotic Bifidobacteria during bread making (direct or indirect) significantly reduced the phytic acid concentration 
in final bread compared to control samples. Fe-dialyzable content in samples with Bifidobacteria was increased to 2.3-5.6-fold. The results demonstrated the usefulness of phytase-producing Bifidobacteria to reduce phytate during bread making and increase Fe-accessibility. According to Kumar et al. [113], lower myo-inositol phosphate derivatives as hydrolysis products of phytic acid were proved to have potential applications in various health-related aspects such as cell signalling and $\mathrm{Ca}^{2+}$ mobilization in intracellular spaces with several proposed applications as antioxidants [114] and painkillers [115]. Inositol hexakisphosphate and inositol application have revealed inhibition of cancer by Vucenik and Shamsuddin [116]. Microbial phytases produced myo-inositol trisphosphate isomer as an end product of phytate hydrolysis and could be used for the synthesis of myo-inositol phosphate derivatives under various conditions [113].

Production of various food crops (wild, traditional, or ancient), which are genetically very diverse and rich in micronutrients, has decreased and even disappeared. Out of 7000 species ever cultivated by humans, currently, only 30 plant species account for $>95 \%$ of the world's food energy supply. Among different cultivated food and cereal crops, wheat (Triticum aestivum L.) plays a predominantly imperative role in daily energy intake. The modern wheat (T. aestivum L.) cultivars with a high-yield capacity are poor sources of $\mathrm{Fe}$ and $\mathrm{Zn}$, for convention daily desires of humans. Along with different micronutrients such as $\mathrm{Fe}$ and $\mathrm{Zn}$, wheat is rich in antinutritional compounds (phytic acid and phenolic compounds) that reduce biological availability of $\mathrm{Fe}$ and $\mathrm{Zn}$ in the human digestive tract. In general, Fe and $\mathrm{Zn}$ concentrations in commercial wheat cultivars are $20-35 \mathrm{mg} / \mathrm{kg}$. The concentrations of micronutrients are not sufficient for human nutrition in diets with wheat constituting the main source of essential minerals. Hence, such wheat-based diets consumed over a period of time can result in micronutrient malnutrition. Farmers chose to grow more profitable, highly productive cereal crops, leading to a decline in the area under protein and micronutrient-rich legumes. This tendency is evident in a proportional decrease in cereal prices and an increase in price for legumes, fruits, vegetables, animal, and fish protein. At present, biofortification approach is getting much attention to increase the availability of micronutrients, especially $\mathrm{Fe}$ and $\mathrm{Zn}$ in the major food crops. The use of PGP bacteria is becoming an effective approach to substitute synthetic fertilizers, pesticides, and supplements. The selected efficient PGP bacteria mobilize the nutrients by various mechanisms such as acidification, chelation, exchange reactions, and release of organic acids $[21,117,118]$.

Currently, there has been an increased curiosity in the development of new functional foods and their assimilation in a healthy diet. Such products, and especially probiotics, exert a beneficial effect on host gut microbiota after consumption and may be proficient to prevent several diseases [119]. Probiotics are defined as live microbiomes which when administered in adequate amounts confer a health benefit on the host. Bioprocessing has been used to manufacture an ample series of foods and food ingredients ever since the initially verified food preservation by humans. Beneficial microbiomes (archaea, bacteria, and yeast) are widely used to convert raw food materials into many of fermented products. Bioprocessing engineering has developed this further, with the particular production of food. The genus Lactobacillus and other species of Lactobacillus are beneficial microbes of particular interest because of their long history of use [120]. The fermented beverages are traditional products that act as vehicles of probiotics in human diet. The global diversity of the fermented and probiotic foods is presented in table. Among different probiotic microbes, the species of Lactobacillus were the first bacteria used by man for processing foodstuffs [121] and for preserving food by inhibiting invasion by other microbiomes that cause foodborne illness or food spoilage [122]. The term "Probiotic" is used to describe food supplements, specifically designed to improve health, and this concludes the probiotic as a "live microbial feed supplement which beneficially affects the host animal by improving its microbial balance."

The procedures of microorganisms by which they act as probiotics or do their effects are not properly known, but the many studies revealed that they may be involved in modifying the $\mathrm{pH}$ value, may neutralize the pathogens through production of compounds that exerts property of antimicrobial, and may occupy the receptor sites of the pathogens as well as chase them for available nutrient [123]. The role of functional food which includes the probiotics microorganisms in human health is well known. The development of probiotic was totally focused on pharmaceutical applications such a intestinal disorders, acute diarrhea, lactose intolerance, and so on. Antibodies were produced by giving Lactobacillus rhamnosus in infants, and those were suffering from diarrhea. Antibodies present in infants shorter the duration of the diarrhea [124]. Specific probiotics have beneficial immunomodulatory effects for the Helicobacter pyloriassociated gastritis [125], and growth of allergies or decrease in allergy symptoms (Table 2) [126].

Probiotics have the property to enhance the immune system. A better precise immune response to a Salmonella typhi oral vaccine has been described in persons consuming a probiotic containing Lactobacillus johnsonii and Bifidobacterium lactis [145], and Lactobacillus fermentum showed positive results for influenza [146]. Probiotics containing Lactobacillus gasseri, Bifidobacterium longum, and Bifidobacterium bifidum concise the duration of common cold and reduced fever [147]. Irritable bowel syndrome, one of the most common disorders seen by primary care physicians, affects $7-10 \%$ of the world population. In the absence of an efficient therapy with no side effects, well-selected probiotic strains might provide a valuable alternative such as Bifidobacterium infantis [148]. The lactose converted into lactic acid with use of lactic acid bacteria (Carnobacterium, Enterococcus, Lactobacillus, Lactococcus, Leuconostoc, Oenococcus, Pediococcus, Streptococcus, Tetragenococcus, Vagococcus, and Weisella) ingestion of certain active strains may help lactose intolerance individuals tolerate more lactose than they would have otherwise. Intestinal discomfort and constipation that represents the most ubiquitous problem among the general adult people were also checked by a probiotic fermented milk containing Bifidobacterium animalis [149]. Lactobacillus paracasei improved recovery of skin immune homeostasis [150]. Probiotics have also impact on anxiety, mood, and behavior; the first human trials suggest that probiotic interventions may modulate mood and stressinduced gastro-intestinal symptoms $[151,152]$.

\section{CONCLUSION AND FUTURE PROSPECT}

The plant microbiomes and microbiomes from different extreme habitats represent the richest extent of molecular and chemical diversity in nature. The explorations of microbial diversity have been spurred due to beneficial role of microbes for sustainable agriculture (microbes may be used as biofertilizers/bioinoculants), for human welfare (microbes with probiotics properties may be used as foods), and for industry (microbes may be used for the production of different compounds of pharmaceutical importance). The beneficial microbes may play an important role in nutrient cycling and environmental detoxification. The microbiomes abound in all kind of habitats, namely, with extremes of $\mathrm{pH}$, temperature, salinity, and water stress 
Yadav, et al.: Journal of Applied Biology \& Biotechnology 2017;5(6):45-57

Table 2: Probiotic microbes in fermented food products its distributions worldwide.

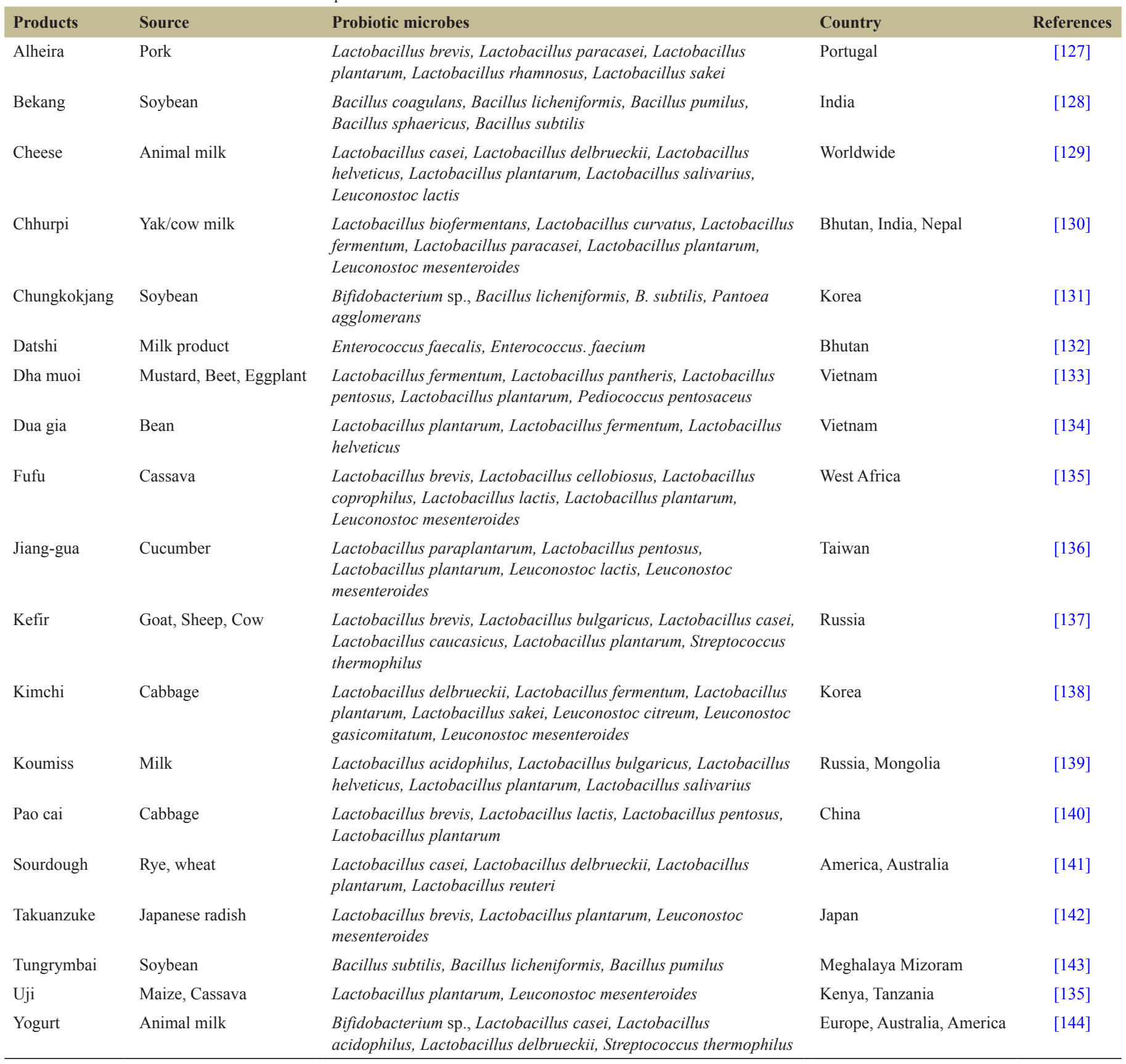

are said to be beneficial for agriculture, and human health as they could be used as PGP agents (biofertilizers) for sustainable agriculture and biofortification of micronutrients such as $\mathrm{Fe}$ and $\mathrm{Zn}$ and as probiotics as new functional foods.

\section{ACKNOWLEDGMENT}

The authors duly acknowledge the Department of Biotechnology, Government of India, for the financial support provided (Grant No. BT/AGR/BIOFORTI/PHII/NIN/2011), Ministry of Food Processing Industries (MoFPI), Government of India, grant for infrastructural facility development (F.No. 5-11/2010-HRD), and Vice Chancellor, Eternal University, for providing the motivation and research infrastructure.

\section{REFERENCES}

1. DeLong EF, Pace NR. Environmental diversity of bacteria and archaea. Syst Biol 2001;50:470-8.

2. Saxena AK, Kaushik R, Yadav AN, Gulati S, Sharma D. Role of archaea in sustenance of plants in extreme saline environments. In: $56^{\text {th }}$ Annual Conference of Association of Microbiologists of India and International Symposium on Emerging Discoveries in Microbiology; 2015.

3. Verma P, Yadav AN, Shukla L, Saxena AK, Suman A. Hydrolytic enzymes production by thermotolerant Bacillus altitudinis IARIMB-9 and Gulbenkiania mobilis IARI-MB-18 isolated from Manikaran hot springs. Int J Adv Res 2015;3:1241-50.

4. Kumar M, Yadav AN, Tiwari R, Prasanna R, Saxena AK. Deciphering 
the diversity of culturable thermotolerant bacteria from Manikaran hot springs. Ann Microbiol 2014;64:741-51.

5. Suman A, Verma P, Yadav AN, Saxena AK. Bioprospecting for extracellular hydrolytic enzymes from culturable thermotolerant bacteria isolated from Manikaran thermal springs. Res J Biotechnol 2015;10:33-42.

6. Sahay H, Yadav AN, Singh AK, Singh S, Kaushik R, Saxena AK. Hot springs of Indian Himalayas: Potential sources of microbial diversity and thermostable hydrolytic enzymes. 3 Biotech 2017;7:1-11.

7. Yadav AN, Sachan SG, Verma P, Saxena AK. Prospecting cold deserts of north western Himalayas for microbial diversity and plant growth promoting attributes. J Biosci Bioeng 2015;119:683-93.

8. Yadav AN, Sachan SG, Verma P, Tyagi SP, Kaushik R, Saxena AK. Culturable diversity and functional annotation of psychrotrophic bacteria from cold desert of Leh Ladakh (India). World J Microbiol Biotechnol 2015;31:95-108.

9. Yadav AN, Verma P, Sachan SG, Saxena AK. Biodiversity and biotechnological applications of psychrotrophic microbes isolated from Indian Himalayan regions. EC Microbiol 2017;ECO.01:48-54.

10. Pandey S, Singh S, Yadav AN, Nain L, Saxena AK. Phylogenetic diversity and characterization of novel and efficient cellulase producing bacterial isolates from various extreme environments. Biosci Biotechnol Biochem 2013;77:1474-80.

11. Saxena AK, Yadav AN, Rajawat M, Kaushik R, Kumar R, Kumar M, et al. Microbial diversity of extreme regions: An unseen heritage and wealth. Indian J Plant Genet Resour 2016;29:246-8.

12. Verma P, Yadav AN, Kazy SK, Saxena AK, Suman A. Evaluating the diversity and phylogeny of plant growth promoting bacteria associated with wheat (Triticum aestivum) growing in central zone of India. Int J Curr Microbiol Appl Sci 2014;3:432-47.

13. Verma P, Yadav AN, Khannam KS, Mishra S, Kumar S, Saxena AK, et al. Appraisal of diversity and functional attributes of thermotolerant wheat associated bacteria from the peninsular zone of India. Saudi J Biol Sci 2016. DOI: org/10.1016/j.sjbs.2016.01.042

14. Yadav S, Kaushik R, Saxena AK, Arora DK. Diversity and phylogeny of plant growth-promoting bacilli from moderately acidic soil. J Basic Microbiol 2011;51:98-106.

15. Verma P, Yadav AN, Kazy SK, Saxena AK, Suman A. Elucidating the diversity and plant growth promoting attributes of wheat (Triticum aestivum) associated acidotolerant bacteria from southern hills zone of India. Natl J Life Sci 2013;10:219-27.

16. Yadav AN. Agriculturally important microbiomes: Biodiversity and multifarious PGP attributes for amelioration of diverse abiotic stresses in crops for sustainable agriculture. Biomed J Sci Tech Res 2017;1:1-4.

17. Verma S, Varma A, Rexer KH, Hassel A, Kost G, Sarbhoy A, et al. Piriformospora indica, gen. et sp. nov., a new root-colonizing fungus. Mycologia 1998;90:896-903.

18. Glick BR. Introduction to plant growth-promoting bacteria. In: Beneficial Plant-Bacterial Interactions. Heidelberg: Springer; 2015. p. 1-28.

19. Tilak K, Ranganayaki N, Pal K, De R, Saxena A, Nautiyal CS, et al. Diversity of plant growth and soil health supporting bacteria. Curr Sci 2005;89:136-50.

20. Yadav AN, Verma P, Kour D, Rana KL, Kumar V, Singh B, et al. Plant microbiomes and its beneficial multifunctional plant growth promoting attributes. J Environ Sci Nat Resour 2017;3:1-8.

21. Verma P, Yadav AN, Kumar V, Kumar K, Dhaliwal HS. Microbes mediated biofortification of wheat (Triticum aestivum L.) for micronutrients by Fe-chelating and $\mathrm{Zn}$-solubilizing bacteria. In: Proceeding of National Conference on Advances in Food Science and Technology; 2017. p. 199.

22. Suman A, Yadav AN, Verma P. Endophytic microbes in crops: Diversity and beneficial impact for sustainable agriculture. In: Singh DP, Abhilash PC, Prabha R, editors. Microbial Inoculants in
Sustainable Agricultural Productivity, Research Perspectives. India: Springer-Verlag; 2016. p. 117-43.

23. Holland MA, Davis R, Moffitt S, O'Laughlin K, Peach D, Sussan S, et al. Using "leaf prints" to investigate a common bacterium. Am Biol Teach 2000;62:128-31.

24. Hornschuh M, Grotha R, Kutschera U. Epiphytic bacteria associated with the bryophyte Funaria hygrometrica: Effects of methylobacterium strains on protonema development. Plant Biol 2002;4:682-7.

25. Mukhtar I, Khokhar I, Sobia M, Ali A. Diversity of epiphytic and endophytic microorganisms in some dominant weeds. Pak J Weed Sci Res 2010;16:287-97.

26. Meena KK, Kumar M, Kalyuzhnaya MG, Yandigeri MS, Singh DP, Saxena AK, et al. Epiphytic pink-pigmented methylotrophic bacteria enhance germination and seedling growth of wheat (Triticum aestivum) by producing phytohormone. Antonie Van Leeuwenhoek 2012;101:777-86.

27. Dobrovol'skaya T, Khusnetdinova K, Manucharova N, Golovchenko A. Structure of epiphytic bacterial communities of weeds. Microbiology 2017;86:257-63.

28. Verma P, Yadav AN, Khannam KS, Panjiar N, Kumar S, Saxena AK, et al. Assessment of genetic diversity and plant growth promoting attributes of psychrotolerant bacteria allied with wheat (Triticum aestivum) from the northern hills zone of India. Ann Microbiol 2015;65:1885-99.

29. Misaghi I, Donndelinger C. Endophytic bacteria in symptom-free cotton plants. Phytopathology 1990;80:808-11.

30. de Bruijn FJ, Stoltzfus JR, So R, Malarvithi PP, Ladha JK. Isolation of endophytic bacteria from rice and assessment of their potential for supplying rice with biologically fixed nitrogen. In: Ladha JK, de Bruijn FJ, Malik KA, editors. Opportunities for Biological Nitrogen Fixation in Rice and Other Non-Legumes. Netherlands: Springer; 1997. p. 25-36.

31. Sturz A, Christie B, Matheson B, Arsenault W, Buchanan N. Endophytic bacterial communities in the periderm of potato tubers and their potential to improve resistance to soil-borne plant pathogens. Plant Pathol 1999;48:360-9.

32. Rana KL, Kour D, Yadav AN, Kumar V, Dhaliwal HS. Endophytic microbes from wheat: Diversity and biotechnological applications for sustainable agriculture. In: Proceeding of $57^{\text {th }}$ Association of Microbiologist of India and International symposium on Microbes and Biosphere: What's New What's Next; 2016. p. 453.

33. Yadav AN, Rana KL, Kumar V, Dhaliwal HS. Phosphorus solubilizing endophytic microbes: Potential application for sustainable agriculture. EU Voice 2016;2:21-2.

34. Yadav AN. Bacterial diversity of cold deserts and mining of genes for low temperature tolerance. Ph.D. Thesis, Birla Institute of Technology, Ranchi and Indian Agricultural Research Institute, New Delhi. 2015; p. 234, DOI: 10.13140/RG.2.1.2948.1283/2

35. Shukla L, Suman A, Yadav AN, Verma P, Saxena AK. Syntrophic microbial system for ex-situ degradation of paddy straw at low temperature under controlled and natural environment. J Appl Biol Biotechnol 2016;4:30-7.

36. Yadav AN, Verma P, Kumar V, Sachan SG, Saxena AK. Extreme cold environments: A suitable niche for selection of novel psychrotrophic microbes for biotechnological applications. Adv Biotechnol Microbiol 2017;2:1-4.

37. Kumar M, Yadav AN, Tiwari R, Prasanna R, Saxena AK. Evaluating the diversity of culturable thermotolerant bacteria from four hot springs of India. J Biodivers Bioprospect Dev 2014;1:1-9.

38. Yadav AN, Sharma D, Gulati S, Singh S, Dey R, Pal KK, et al. Haloarchaea endowed with phosphorus solubilization attribute implicated in phosphorus cycle. Sci Rep 2015;5:12293.

39. Yadav AN, Verma P, Kumar M, Pal KK, Dey R, Gupta A, et al. Diversity and phylogenetic profiling of niche-specific Bacilli from 
extreme environments of India. Ann Microbiol 2015;65:611-29.

40. Bowman JP. Description of Cellulophaga algicola sp. nov. isolated from the surfaces of Antarctic algae, and reclassification of Cytophaga uliginosa (ZoBell and Upham 1944) Reichenbach 1989 as Cellulophaga uliginosa comb. nov. Int J Syst Evol Microbiol 2000;50:1861-8.

41. Reddy G, Pradhan S, Manorama R, Shivaji S. Cryobacterium roopkundense sp. nov., a psychrophilic bacterium isolated from glacial soil. Int J Syst Evol Microbiol 2010;60:866-70.

42. Chaturvedi P, Prabahar V, Manorama R, Pindi PK, Bhadra B, Begum Z, et al. Exiguobacterium soli sp. nov. a psychrophilic bacterium from the McMurdo Dry Valleys, Antarctica. Int J Syst Evol Microbiol 2008;58:2447-53.

43. Humphry DR, George A, Black GW, Cummings SP. Flavobacterium frigidarium sp. nov., an aerobic, psychrophilic, xylanolytic and laminarinolytic bacterium from Antarctica. Int J Syst Evol Microbiol 2001;51:1235-43.

44. Van Trappen S, Vandecandelaere I, Mergaert J, Swings J. Flavobacterium fryxellicola sp. nov. and Flavobacterium psychrolimnae sp. nov. novel psychrophilic bacteria isolated from microbial mats in Antarctic lakes. Int J Syst Evol Microbiol 2005;55:769-72.

45. Margesin R, Zhang DC, Frasson D, Brouchkov A. Glaciimonas frigoris sp. nov., a psychrophilic bacterium isolated from ancient Siberian permafrost sediment, and emended description of the genus Glaciimonas. Int J Syst Evol Microbiol 2016;66:744-8.

46. Hirsch P, Ludwig W, Hethke C, Sittig M, Hoffmann B, Gallikowski CA. Hymenobacter roseosalivarius gen. nov. sp. nov. from continental Antartica soils and sandstone: Bacteria of the Cytophaga/Flavobacterium/Bacteroides line of phylogenetic descent. Syst Appl Microbiol 1998;21:374-83.

47. Lee YM, Hwang CY, Lee I, Jung YJ, Cho Y, Baek K, et al. Lacinutrix jangbogonensis sp. nov. a psychrophilic bacterium isolated from Antarctic marine sediment and emended description of the genus Lacinutrix. Antonie Van Leeuwenhoek 2014;106:527-33.

48. Shen L, Liu Y, Gu Z, Xu B, Wang N, Jiao N, et al. Massilia eurypsychrophila sp. nov. a facultatively psychrophilic bacteria isolated from ice core. Int J Syst Evol Microbiol 2015;65:2124-9.

49. Gosink J, Herwig R, Staley J. Octadecabacter arcticus gen. nov., sp. nov., and $O$. antarcticus, sp. nov., nonpigmented, psychrophilic gas vacuolate bacteria from polar sea ice and water. Syst Appl Microbiol 1997;20:356-65.

50. Yakimov MM, Giuliano L, Gentile G, Crisafi E, Chernikova TN, Abraham WR, et al. Oleispira antarctica gen. nov. sp. nov. a novel hydrocarbonoclastic marine bacterium isolated from Antarctic coastal sea water. Int J Syst Evol Microbiol 2003;53:779-85.

51. Zhou Z, Jiang F, Wang S, Peng F, Dai J, Li W, et al. Pedobacter arcticus sp. nov. a facultative psychrophile isolated from Arctic soil, and emended descriptions of the genus Pedobacter, Pedobacter heparinus, Pedobacter daechungensis, Pedobacter terricola, Pedobacter glucosidilyticus and Pedobacter lentus. Int J Syst Evol Microbiol 2012;62:1963-9.

52. López NI, Pettinari MJ, Stackebrandt E, Tribelli PM, Põtter M, Steinbüchel A, et al. Pseudomonas extremaustralis sp. nov. a Poly(3hydroxybutyrate) producer isolated from an antarctic environment. Curr Microbiol 2009;59:514-9.

53. Zachariah S, Kumari P, Das SK. Psychrobacter pocilloporae sp. nov., isolated from a coral, Pocillopora eydouxi. Int J Syst Evol Microbiol 2017;66:5091-8.

54. Auman AJ, Breezee JL, Gosink JJ, Kämpfer P, Staley JT. Psychromonas ingrahamii sp. nov. a novel gas vacuolate, psychrophilic bacterium isolated from Arctic polar sea ice. Int J Syst Evol Microbiol 2006;56:1001-7.

55. Albert RA, Waas NE, Pavlons SC, Pearson JL, Ketelboeter L,
Rosselló-Móra R, et al. Sphingobacterium psychroaquaticum sp. nov. a psychrophilic bacterium isolated from Lake Michigan water. Int J Syst Evol Microbiol 2013;63:952-8.

56. Zhang DC, Busse HJ, Liu HC, Zhou YG, Schinner F, Margesin R. Sphingomonas glacialis sp. nov. a psychrophilic bacterium isolated from alpine glacier cryoconite. Int $\mathrm{J}$ Syst Evol Microbiol 2011;61:587-91.

57. Yadav AN, Sachan SG, Verma P, Saxena AK. Bioprospecting of plant growth promoting psychrotrophic Bacilli from the cold desert of north western Indian Himalayas. Indian J Exp Biol 2016;54:142-50.

58. Ravot G, Magot M, Fardeau ML, Patel BK, Prensier G, Egan A, et al. Thermotoga elfii sp. nov. a novel thermophilic bacterium from an African oil-producing well. Int J Syst Bacteriol 1995;45:308-14.

59. Fardeau ML, Ollivier B, Patel BK, Magot M, Thomas P, Rimbault A, et al. Thermotoga hypogea sp. nov. a xylanolytic, thermophilic bacterium from an oil-producing well. Int J Syst Bacteriol 1997;47:1013-9.

60. Wagner ID, Zhao W, Zhang CL, Romanek CS, Rohde M, Wiegel J. Thermoanaerobacter uzonensis sp. nov. an anaerobic thermophilic bacterium isolated from a hot spring within the Uzon Caldera, Kamchatka, Far East Russia. Int J Syst Evol Microbiol 2008;58:2565-73.

61. Mori K, Yamazoe A, Hosoyama A, Ohji S, Fujita N, Ishibashi J, et al. Thermotoga profunda sp. nov. and Thermotoga caldifontis sp. nov. anaerobic thermophilic bacteria isolated from terrestrial hot springs. Int J Syst Evol Microbiol 2014;64:2128-36.

62. Koeck DE, Hahnke S, Zverlov VV. Herbinix luporum sp. nov. a thermophilic cellulose-degrading bacterium isolated from a thermophilic biogas reactor. Int J Syst Evol Microbiol 2016;66:4132-7.

63. Gaba S, Singh RN, Abrol S, Yadav AN, Saxena AK, Kaushik R. Draft genome sequence of Halolamina pelagica CDK2 isolated from natural salterns from Rann of Kutch, Gujarat, India. Genome Announc 2017;5:1-2.

64. Yadav AN, Verma P, Kaushik R, Dhaliwal HS, Saxena AK. Archaea endowed with plant growth promoting attributes. EC Microbiol 2017;8:294-8.

65. Giller KE. Nitrogen Fixation in Tropical Cropping Systems. UK: CABI; 2001.

66. Elbeltagy A, Nishioka K, Sato T, Suzuki H, Ye B, Hamada T, et al. Endophytic colonization and in planta nitrogen fixation by a Herbaspirillum sp. isolated from wild rice species. Appl Environ Microbiol 2001;67:5285-93.

67. Boddey RM, Urquiaga S, Alves BJ, Reis V. Endophytic nitrogen fixation in sugarcane: Present knowledge and future applications. Plant Soil 2003;252:139-49.

68. Wei CY, Lin L, Luo LJ, Xing YX, Hu CJ, Yang LT, et al. Endophytic nitrogen-fixing Klebsiella variicola strain DX120E promotes sugarcane growth. Biol Fertil Soils 2014;50:657-66.

69. Reis VM, Teixeira KR. Nitrogen fixing bacteria in the family Acetobacteraceae and their role in agriculture. J Basic Microbiol 2015;55:931-49.

70. Suman A, Verma P, Yadav AN, Srinivasamurthy R, Singh A, Prasanna R. Development of hydrogel based bio-inoculant formulations and their impact on plant biometric parameters of wheat (Triticum aestivum L.). Int J Curr Microbiol Appl Sci 2016;5:890-901.

71. Singh RN, Gaba S, Yadav AN, Gaur P, Gulati S, Kaushik R, et al. First high quality draft genome sequence of a plant growth promoting and cold active enzyme producing psychrotrophic Arthrobacter agilis strain L77. Stand Genomic Sci 2016;11:54.

72. Yadav AN, Verma P, Singh B, Chauhan VS, Suman A, Saxena AK. Plant growth promoting bacteria: Biodiversity and multifunctional attributes for sustainable agriculture. Adv Biotechnol Microbiol 2017;5:1-16. 
73. Barra PJ, Inostroza NG, Acuña JJ, Mora ML, Crowley DE, Jorquera MA. Formulation of bacterial consortia from avocado (Persea americana Mill.) and their effect on growth, biomass and superoxide dismutase activity of wheat seedlings under salt stress. Appl Soil Ecol 2016;102:80-91.

74. Ashraf M, Hasnain S, Berge O, Mahmood T. Inoculating wheat seedlings with exopolysaccharide-producing bacteria restricts sodium uptake and stimulates plant growth under salt stress. Biol Fertil Soils 2004;40:157-62.

75. Jha A, Saxena J, Sharma V. Investigation on phosphate solubilization potential of agricultural soil bacteria as affected by different phosphorus sources, temperature, salt, and $\mathrm{pH}$. Commun Soil Sci Plant Anal 2013;44:2443-58.

76. Kasim WA, Osman ME, Omar MN, Abd El-Daim IA, Bejai S, Meijer J. Control of drought stress in wheat using plant-growthpromoting bacteria. J Plant Growth Regul 2013;32:122-30.

77. Alvarez M, Sueldo R, Barassi C. Effect of Azospirillum on coleoptile growth in wheat seedlings under water stress. Cereal Res Commun 1996;24:101-7.

78. Creus CM, Sueldo RJ, Barassi CA. Water relations and yield in Azospirillum-inoculated wheat exposed to drought in the field. Can J Bot 2004;82:273-81.

79. Turan M, Gulluce M, Şahin F. Effects of plant-growth-promoting rhizobacteria on yield, growth, and some physiological characteristics of wheat and barley plants. Commun Soil Sci Plant Anal 2012;43:1658-73.

80. Arzanesh MH, Alikhani H, Khavazi K, Rahimian H, Miransari M. Wheat (Triticum aestivum L.) growth enhancement by Azospirillum sp. under drought stress. World J Microbiol Biotechnol 2011;27:197-205.

81. Verma P, Yadav AN, Khannam KS, Kumar S, Saxena AK, Suman A, et al. Molecular diversity and multifarious plant growth promoting attributes of Bacilli associated with wheat (Triticum aestivum L.) rhizosphere from six diverse agro-ecological zones of India. J Basic Microbiol 2016;56:44-58.

82. Verma P, Yadav AN, Shukla L, Saxena AK, Suman A. Alleviation of cold stress in wheat seedlings by Bacillus amyloliquefaciens IARIHHS2-30, an endophytic psychrotolerant K-solubilizing bacterium from NW Indian Himalayas. Natl J Life Sci 2015;12:105-10.

83. Singh RP, Jha PN. A halotolerant bacterium Bacillus licheniformis HSW-16 augments induced systemic tolerance to salt stress in wheat plant (Triticum aestivum). Front Plant Sci 2016;7:1890.

84. Chakraborty U, Chakraborty BN, Chakraborty AP, Dey PL. Water stress amelioration and plant growth promotion in wheat plants by osmotic stress tolerant bacteria. World J Microbiol Biotechnol 2013;29:789-803.

85. Naveed M, Hussain MB, Zahir ZA, Mitter B, Sessitsch A. Drought stress amelioration in wheat through inoculation with Burkholderia phytofirmans strain PsJN. Plant Growth Regul 2014;73:121.

86. Sezen A, Ozdal M, Koc K, Algur OF. Isolation and characterization of plant growth promoting rhizobacteria (PGPR) and their effects on improving growth of wheat. J Appl Biol Sci 2016;10:41-6.

87. Rana KL, Kour D, Verma P, Yadav AN, Kumar V, Singh DH. Diversity and biotechnological applications of endophytic microbes associated with maize (Zea mays L.) growing in Indian Himalayan regions. In: Proceeding of National Conference on Advances in Food Science and Technology; 2017.

88. El-Azeem SA, Mehana TA, Shabayek AA. Effect of seed inoculation with plant growth-promoting rhizobacteria on the growth and yield of wheat (Triticum aestivum L.) cultivated in a sandy soil. In: Proceedings of the Third International Conference on Future Trends in Genetics and Biotechnology for Safe Environment; 2008. p. 69-74.

89. Chen C, Xin K, Liu H, Cheng J, Shen X, Wang Y, et al. Pantoea alhagi, a novel endophytic bacterium with ability to improve growth and drought tolerance in wheat. Sci Rep 2017;7:41564.

90. Yaghoubian Y, Goltapeh EM, Pirdashti H, Esfandiari E, Feiziasl V, Dolatabadi HK, et al. Effect of Glomus mosseae and Piriformospora indica on growth and antioxidant defense responses of wheat plants under drought stress. Agric Res 2014;3:239-45.

91. Abbaspoor A, Zabihi HR, Movafegh S, Asl MA. The efficiency of plant growth promoting rhizobacteria (PGPR) on yield and yield components of two varieties of wheat in salinity condition. Am Eurasian J Sustain Agric 2009;3:824-8.

92. Selvakumar G, Joshi P, Suyal P, Mishra PK, Joshi GK, Bisht JK, et al. Pseudomonas lurida M2RH3 (MTCC 9245), a psychrotolerant bacterium from the Uttarakhand Himalayas, solubilizes phosphate and promotes wheat seedling growth. World J Microbiol Biotechnol 2011;27:1129-35.

93. Ali SZ, Sandhya V, Grover M, Linga VR, Bandi V. Effect of inoculation with a thermotolerant plant growth promoting Pseudomonas putida strain AKMP7 on growth of wheat (Triticum spp.) under heat stress. J Plant Interact 2011;6:239-46.

94. Mishra PK, Mishra S, Bisht SC, Selvakumar G, Kundu S, Bisht JK, et al. Isolation, molecular characterization and growth-promotion activities of a cold tolerant bacterium Pseudomonas sp. NARs9 (MTCC9002) from the Indian Himalayas. Biol Res 2009;42:305-13.

95. Kumar V, Singh P, Jorquera MA, Sangwan P, Kumar P, Verma AK, et al. Isolation of phytase-producing bacteria from Himalayan soils and their effect on growth and phosphorus uptake of Indian mustard (Brassica juncea). World J Microbiol Biotechnol 2013;29:1361-9.

96. Kaur R, Saxena A, Sangwan P, Yadav AN, Kumar V, Dhaliwal HS. Production and characterization of a neutral phytase of Penicillium oxalicum EUFR-3 isolated from Himalayan region. Nusantara Biosci 2017;9:68-76

97. Li M, Osaki M, Rao IM, Tadano T. Secretion of phytase from the roots of several plant species under phosphorus-deficient conditions. Plant Soil 1997;195:161-9.

98. Kumar V, Singh G, Verma AK, Agrawal S. In silico characterization of histidine acid phytase sequences. Enzyme Res 2012;2012:845465.

99. Kumar V, Singh D, Sangwan P, Gill PK. Management of environmental phosphorus pollution using phytases: Current challenges and future prospects. In: Applied Environmental Biotechnology: Present Scenario and Future Trends. New Delhi: Springer; 2015. p. 97-114.

100. Singh P, Kumar V, Agrawal S. Evaluation of phytase producing bacteria for their plant growth promoting activities. Int J Microbiol 2014;2014:426483.

101. Kumar V, Sangwan P, Verma AK, Agrawal S. Molecular and biochemical characteristics of recombinant $\beta$-propeller phytase from Bacillus licheniformis strain PB-13 with potential application in aquafeed. Appl Biochem Biotechnol 2014;173:646-59.

102. Huang H, Shao N, Wang Y, Luo H, Yang P, Zhou Z, et al. A novel beta-propeller phytase from Pedobacter nyackensis MJ11 CGMCC 2503 with potential as an aquatic feed additive. Appl Microbiol Biotechnol 2009;83:249-59.

103. Lottmann J, Heuer H, De Vries J, Mahn A, Düring K, Wackernagel W, et al. Establishment of introduced antagonistic bacteria in the rhizosphere of transgenic potatoes and their effect on the bacterial community. FEMS Microbiol Ecol 2000;33:41-9.

104. Yadav AN, Sachan SG, Verma P, Kaushik R, Saxena AK. Cold active hydrolytic enzymes production by psychrotrophic Bacilli isolated from three sub-glacial lakes of NW Indian Himalayas. J Basic Microbiol 2016;56:294-307.

105. Yadav AN, Verma P, Kumar R, Kumar V, Kumar K. Current applications and future prospects of eco-friendly microbes. EU Voice 2017;3:21-2.

106. Kour D, Rana KL, Verma P, Yadav AN, Kumar V, Singh DH. Biofertilizers: Eco-friendly technologies and bioresources for 
sustainable agriculture. In: Proceeding of International Conference on Innovative Research in Engineering Science and Technology; 2017.

107. Penella JS, Collar C, Haros M. Effect of wheat bran and enzyme addition on dough functional performance and phytic acid levels in bread. J Cereal Sci 2008;48:715-21.

108. Hurrell RF, Reddy MB, Juillerat MA, Cook JD. Degradation of phytic acid in cereal porridges improves iron absorption by human subjects. Am J Clin Nutr 2003;77:1213-9.

109. Jin F, Frohman C, Thannhauser TW, Welch RM, Glahn RP. Effects of ascorbic acid, phytic acid and tannic acid on iron bioavailability from reconstituted ferritin measured by an in vitro digestion-Caco-2 cell model. Br J Nutr 2009;101:972-81.

110. Frontela C, Scarino ML, Ferruzza S, Ros G, Martínez C. Effect of dephytinization on bioavailability of iron, calcium and zinc from infant cereals assessed in the Caco-2 cell model. World J Gastroenterol 2009;15:1977-84.

111. Park YJ, Park J, Park KH, Oh BC, Auh JH. Supplementation of alkaline phytase (Ds11) in whole-wheat bread reduces phytate content and improves mineral solubility. J Food Sci 2011;76:C791-4.

112. Sanz-Penella JM, Laparra JM, Sanz Y, Haros M. Assessment of iron bioavailability in whole wheat bread by addition of phytaseproducing bifidobacteria. J Agric Food Chem 2012;60:3190-5.

113. Kumar V, Yadav AN, Verma P, Sangwan P, Saxena A, Kumar K, et al. B-Propeller phytases: Diversity, catalytic attributes, current developments and potential biotechnological applications. Int J Biol Macromol 2017;98:595-609.

114. Phillippy BQ, Graf E. Antioxidant functions of inositol 1,2,3-trisphosphate and inositol 1,2,3,6-tetrakisphosphate. Free Radic Biol Med 1997;22:939-46.

115. Siren M. Method of Treating Pain Using Inositol Triphosphate, Google Patents; 1995.

116. Vucenik I, Shamsuddin AM. Cancer inhibition by inositol hexaphosphate (IP6) and inositol: From laboratory to clinic. J Nutr 2003;133 11 Suppl 1:3778S-84.

117. Saxena AK, Yadav AN, Kaushik R, Tyagi S, Kumar M, Prasanna R, et al. Use of microbes from extreme environments for the benefits of agriculture. In: Afro-Asian Congress on Microbes for Human and Environmental Health; 2014.

118. Saxena AK, Yadav AN, Kaushik R, Tyagi SP, Shukla L. Biotechnological applications of microbes isolated from cold environments in agriculture and allied sectors. In: International Conference on Low Temperature Science and Biotechnological Advances, Society of Low Temperature Biology; 2015. p. 104.

119. Kandylis P, Pissaridi K, Bekatorou A, Kanellaki M, Koutinas AA. Dairy and non-dairy probiotic beverages. Curr Opin Food Sci 2016;7:58-63.

120. Holzapfel WH. Appropriate starter culture technologies for smallscale fermentation in developing countries. Int J Food Microbiol 2002; 75:197-212.

121. Konings WN, Kok J, Kuipers OP, Poolman B. Lactic acid bacteria: The bugs of the new millennium. Curr Opin Microbiol 2000;3:276-82.

122. Adams MR. Safety of industrial lactic acid bacteria. J Biotechnol 1999;68:171-8.

123. Lee IC, Caggianiello G, van Swam II, Taverne N, Meijerink M, Bron PA, et al. Strain-specific features of extracellular polysaccharides and their impact on Lactobacillus plantarum-host interactions. Appl Environ Microbiol 2016;82:3959-70.

124. Vlasova AN, Kandasamy S, Chattha KS, Rajashekara G, Saif LJ. Comparison of probiotic lactobacilli and bifidobacteria effects, immune responses and rotavirus vaccines and infection in different host species. Vet Immunol Immunopathol 2016;172:72-84.

125. McFarland LV, Malfertheiner P, Huang Y, Wang L. Meta-analysis of single strain probiotics for the eradication of Helicobacter pylori and prevention of adverse events. World J Meta Anal 2015;3:97-117.

126. Prescott SL, Björkstén B. Probiotics for the prevention or treatment of allergic diseases. J Allergy Clin Immunol 2007;120:255-62.

127. Albano H, van Reenen CA, Todorov SD, Cruz D, Fraga L, Hogg T, et al. Phenotypic and genetic heterogeneity of lactic acid bacteria isolated from "Alheira", a traditional fermented sausage produced in Portugal. Meat Sci 2009;82:389-98.

128. Chettri R, Tamang JP. Bacillus species isolated from tungrymbai and bekang, naturally fermented soybean foods of India. Int J Food Microbiol 2015;197:72-6.

129. Parente E, Cogan T. Starter cultures: General aspects. Cheese Chem Phys Microbiol 2004;1:123-47.

130. Tamang J, Dewan S, Thapa S, Olasupo N, Schillinger U, Wijaya A, et al. Identification and enzymatic profiles of the predominant lactic acid bacteria isolated from soft variety Chhurpi, a traditional cheese typical of the Sikkim Himalayas. Food Biotechnol 2000;14:99-112.

131. Hong SB, Kim DH, Lee M, Baek SY, Kwon SW, Houbraken J, et al. Zygomycota associated with traditional meju, a fermented soybean starting material for soy sauce and soybean paste. J Microbiol 2012;50:386-93.

132. Shangpliang HN, Sharma S, Rai R, Tamang JP. Some technological properties of lactic acid bacteria isolated from Dahi and Datshi, naturally fermented milk products of Bhutan. Front Microbiol 2017;8:116.

133. Nguyen DT, Van Hoorde K, Cnockaert M, De Brandt E, Aerts M, Binh Thanh L, et al. A description of the lactic acid bacteria microbiota associated with the production of traditional fermented vegetables in Vietnam. Int J Food Microbiol 2013;163:19-27.

134. Phan YT, Tang MT, Tran TT, Nguyen VH, Nguyen TH, Tsuruta T, et al. Diversity of lactic acid bacteria in vegetable-based and meatbased fermented foods produced in the central region of Vietnam. AIMS Microbiol 2017;3:61-70.

135. Oyewole OB. Lactic fermented foods in Africa and their benefits. Food Control 1997;8:289-97.

136. Chen YS, Wu HC, Lo HY, Lin WC, Hsu WH, Lin CW, et al. Isolation and characterisation of lactic acid bacteria from jiang-gua (fermented cucumbers), a traditional fermented food in Taiwan. J Sci Food Agric 2012;92:2069-75.

137. Bernardeau M, Guguen M, Vernoux JP. Beneficial lactobacilli in food and feed: Long-term use, biodiversity and proposals for specific and realistic safety assessments. FEMS Microbiol Rev 2006;30:487-513.

138. Jung JY, Lee SH, Kim JM, Park MS, Bae JW, Hahn Y, et al. Metagenomic analysis of Kimchi, a traditional Korean fermented food. Appl Environ Microbiol 2011;77:2264-74.

139. Hao Y, Zhao L, Zhang H, Zhai Z, Huang Y, Liu X, et al. Identification of the bacterial biodiversity in koumiss by denaturing gradient gel electrophoresis and species-specific polymerase chain reaction. J Dairy Sci 2010;93:1926-33.

140. Yan PM, Xue WT, Tan SS, Zhang H, Chang XH. Effect of inoculating lactic acid bacteria starter cultures on the nitrite concentration of fermenting Chinese paocai. Food Control 2008;19:50-5.

141. De Vuyst L, Vrancken G, Ravyts F, Rimaux T, Weckx S. Biodiversity, ecological determinants, and metabolic exploitation of sourdough microbiota. Food Microbiol 2009;26:666-75.

142. Alexandraki V, Tsakalidou E, Papadimitriou K, Holzapfel W. Status and Trends of the Conservation and Sustainable Use of MicroOrganisms in Food Processes. Background Study Paper (FAO); 2013.

143. Chettri R, Tamang J. Organoleptic evaluation of tungrymbai and bekang, naturally fermented soybean foods, produced by using selected species of Bacillus. J Sci Ind Res 2016;75:416-9.

144. Tamime AY, Robinson RK. Tamime and Robinson's Yoghurt: Science and Technology. Cambridge, U.K: Elsevier; 2007.

145. Olivares M, Díaz-Ropero MP, Sierra S, Lara-Villoslada F, 
Fonollá J, Navas M, et al. Oral intake of Lactobacillus fermentum CECT5716 enhances the effects of influenza vaccination. Nutrition 2007;23:254-60.

146. Arunachalam K, Gill HS, Chandra RK. Enhancement of natural immune function by dietary consumption of Bifidobacterium lactis (HN019). Eur J Clin Nutr 2000;54:263-7.

147. de Vrese M, Winkler P, Rautenberg P, Harder T, Noah C, Laue C, et al. Probiotic bacteria reduced duration and severity but not the incidence of common cold episodes in a double blind, randomized, controlled trial. Vaccine 2006;24:6670-4.

148. Spiegel BM. The burden of IBS: Looking at metrics. Curr Gastroenterol Rep 2009;11:265-9.

149. De Paula JA, Carmuega E, Weill R. Effect of the ingestion of a symbiotic yogurt on the bowel habits of women with functional constipation. Acta Gastroenterol Latinoam 2008;38:16-25.

150. Indrio F, Riezzo $\mathrm{G}$, Raimondi $\mathrm{F}$, Bisceglia $\mathrm{M}$, Cavallo $\mathrm{L}$, Francavilla R. The effects of probiotics on feeding tolerance, bowel habits, and gastrointestinal motility in preterm newborns. J Pediatr 2008;152:801-6.

151. Benton D, Williams C, Brown A. Impact of consuming a milk drink containing a probiotic on mood and cognition. Eur J Clin Nutr 2007;61:355-61.

152. Yadav AN, Verma P, Kumar R, Kumar S, Kumar V, Kumar K, et al. Probiotic microbes: Biodiversity, mechanisms of action and potential role in human health. In: Proceeding of National Conference on Advances in Food Science and Technology; 2017.

\section{How to cite this article:}

Yadav AN, Kumar R, Kumar S, Kumar V, Sugitha TCK, Singh B,

Chauahan VS, Dhaliwal HS, Saxena AK. Beneficial microbiomes:

Biodiversity and potential biotechnological applications for sustainable

agriculture and human health. J App Biol Biotech. 2017;5(6):45-57.

DOI: $10.7324 / \mathrm{JABB} .2017 .50607$. 